\title{
INTENSI MENIKAH PADA MAHASISWA DI MASA PANDEMI COVID-19
}

\author{
Emilia Mustary, Farwan, Sukmawati, Era Fasira \\ Institut Agama Islam Negeri Parepare \\ emiliamustary@iainpare.ac.id, Farwan@iainpare.ac.id, Sukmawati@iainpare.ac.id, \\ Erafasira@iainpare.ac.id
}

\begin{abstract}
This study aims to examine and describe the marriage intention in college students during the COVID-19 pandemic based on the theory of planned behavior from Ajzen (2005) with three determinant factors, namely attitude toward behavior, subjective norm, and perceived behavioral control. This study used a qualitative approach with data collection in the form of interviews with primary data sources. The subjects in this study amounted to 3 female students with the criteria for will getting married and had got engaged. The data analysis technique was carried out using an interactive analysis model by Miles and Huberman, namely data collection, data reduction, data presentation/display, then conclusions or verification. The results showed that the Covid-19 pandemic did not affect the students' marriage intention. Determinants of marriage intentions are formed from attitudes towards the behavior in the form of a positive attitude towards marriage which is obtained from the belief in the positive benefits that are imagined and the description of the risks that will be faced. The next marriage intention is formed by subjective norms in the form of parental influence and the desire to imitate the positive experiences of other students who married while studying. Furthermore, the intention to marry is formed on the determinants of perceived behavioral control factors in the form of the subject's belief in the ability to control behavior to prevent conflict and find solutions to household problems that will be faced stemming from his status as a student. Another finding in this study is that belief in religion and adherence to religious teachings are sources of information that strengthen the determinant factors so as to form a strong intention to marry.
\end{abstract}

Keywords: intention, marriage, college students, covid-19

\begin{abstract}
ABSTRAK
Penelitian ini bertujuan untuk mengkaji dan mendeskripsikan intensi menikah pada mahasiswa di masa pandemi covid-19 berdasarkan teori perencanaan perilaku dari Ajzen (2005) dengan tiga faktor determinan yaitu attitude toward behavior, subjective norm, dan perceived behavioral control. Penelitian ini menggunakan pendekatan kualitatif dengan pengambilan data berupa wawancara pada sumber data primer. Subjek pada penelitian ini berjumlah 3 orang mahasiswi dengan kriteria akan melangsungkan pernikahan dan telah menjalani proses lamaran. Teknik analisis data dilakukan dengan model analisis interaktif oleh Miles dan Huberman yaitu pengumpulan data, reduksi data, presentasi/display data, lalu kesimpulan atau verifikasi. Hasil penelitian menunjukkan bahwa pandemi covoid-19 tidak mempengaruhi intensi menikah pada mahasiswa. Determinan intensi menikah dibentuk dari sikap terhadap perilaku (attitude towards the behavior) berupa sikap positif terhadap pernikahan yang didapatkan dari keyakinan akan manfaat positif yang dibayangkan serta gambaran resiko yang akan dihadapi. Intensi menikah berikutnya dibentuk oleh norma subjektif (subjective norm) berupa pengaruh orangtua serta keinginan untuk meniru pengalaman positif mahasiswa lain yang menikah sambil kuliah. Selanjutnya, intensi menikah dibentuk atas determinan faktor persepsi kontrol perilaku (perceived behavioral control) berupa keyakinan subjek akan kemampuan mengontrol perilaku untuk mencegah konflik maupun menemukan solusi dalam permasalahan rumah tangga yang akan dihadapi yang bersumber dari statusnya sebagai mahasiswa. Temuan lain dalam penelitian ini adalah keyakinan terhadap agama serta kepatuhan terhadap ajaran agama menjadi sumber informasi yang memperkuat faktor determinan sehingga membentuk intensi yang kuat untuk menikah.
\end{abstract}

Kata Kunci: Intensi, mahasiswa, menikah, covid-19. 


\section{PENDAHULUAN}

Dewasa ini kita menjumpai sebuah fenomena menikah yang banyak terjadi pada kalangan mahasiswa. Rentang usia 18-22 tahun yang merupakan rentang usia dewasa awal dimana seseorang memasuki atau biasanya berada pada jenjang pendidikan perguruan tinggi, yaitu Strata 1 (S1) dan disebut sebagai mahasiswa. Sebagian besar golongan dewasa awal yang dijumpai telah menyelesaikan pendidikan pada taraf Strata-1 (S1) dan kemudian segera memasuki jenjang karir dalam pekerjaannya.

Beberapa tahun terakhir, menikah selagi masih menjalankan perkuliahan menjadi tren di kalangan generasi muda, khususnya bagi mahasiswa, baik yang masih menempuh semester awal maupun yang telah mencapai semester akhir dari masa perkuliahan. Pernikahan di kalangan mahasiswa menjadi salah satu upaya penghindari dari perilaku seks bebas. Hal tersebut sejalan dengan penelitian dari Putri, Suyono, dan Tentama (2019) yang mengatakan bahwa kontrol diri memberikan kontribusi dalam perilaku seks pranikah pada remaja atau dapat mencegah dari perilaku seks pranikah

Pernikahan yang terjadi pada pasangan muda yang sekaligus berstatus mahasiswa menuntut adanya peran ganda yang harus dijalani. Menurut Mukarromah dan Nuqul (2012) dalam risetnya yang berjudul "Pengambilan Keputusan Mahasiswa Menikah Saat Kuliah Pada Mahasiswa UIN Maulana Malik Ibrahim Malang" mengemukakan bahwa alasan mahasiswa menikah di masa kuliah karena memiliki anggapan bahwa pernikahan adalah suatu keniscayaan dan jodoh yang datang dari Tuhan. Selain itu, mahasiswa menikah untuk menjaga nama baik diri dan keluarga serta sebagai bentuk kepatuhan anak kepada orang tua.

Riset yang serupa dari Juliawati (2017) dengan judul "Studi Kasus Terhadap Mahasiswa yang Menikah saat Menempuh Masa Kuliah" mengungkapkan bahwa motivasi menikah pasangan mahasiswa diantaranya karena takut berbuat dosa, rasa kasih sayang dan cinta di antara mereka, untuk membuka pintu rezeki, serta dorongan dari orangtua mereka. Sejalan dengan kedua riset sebelumnya, Sari dan Nurwidawati (2013) dengan judul "Studi Kasus Kehidupan Pernikahan Mahasiswa Yang Menikah Saat Menempuh Masa Kuliah" mengemukakan tiga motivasi terbesar mahasiswa untuk menikah adalah rasa saling cinta, tekanan dari orangtua, dan yang cukup berbeda dari riset sebelumnya adalah keinginan mendapatkan keturunan.

Pernikahan di saat kuliah menurut Blood dalam Mukarromah dan Nuqul 
(2012) memiliki permasalahan yang berbeda dari permasalahan-permasalahan pada pernikahan yang umum. Hal-hal yang dapat menyulitkan pernikahan di masa kuliah, di antaranya adalah masalah pembagian peran. Perempuan yang telah menikah akan menghadapi tugas-tugas kerumahtanggaan sesuai dengan perannya sebagai istri, namun juga harus menjalankan perannya sebagai mahasiswi dengan menghadiri perkuliahan, mengerjakan tugas, mengikuti ujian, dan lain-lain. Untuk memenuhi tugas-tugas tersebut maka perlu dilakukan pembagian waktu antara tugas kuliah dan tugas kerumahtanggaan agar terpenuhi secara bersamaan.

Masalah berikutnya adalah masalah keuangan yang digunakan untuk mendanai kebutuhan kehidupan yang dulunya dipakai untuk kepentingan pribadi sekarang dialokasikan untuk kepentingan bersama. Kesempatan pengembangan diri juga menjadi masalah yang dialami oleh mahasiswa kurang memiliki kesempatan untuk memiliki pengalaman lebih, termasuk dalam hal berorganisasi, dibanding teman-temannya dikarenakan waktu untuk berkumpul semakin berkurang.

Hasil riset terdahulu yang menunjukkan permasalahan pernikahan pada masa perkuliahan juga didominasi oleh kesulitan dalam mengatur waktu antara kuliah dan rumah tangga juga dikemukakan oleh Anisaningtyas dan Astuti (2011) yang berjudul "Pernikahan di Kalangan Mahasiswa S1”. Dampak lain yang ditimbulkan dalam pernikahan dengan status mahasiswa yakni kelahiran anak di luar perencanaan. Kelahiran anak dianggap menyulitkan, khususnya pada penyesuaian peran sebagai istri, ibu, dan mahasiswa sehingga pilihan untuk mengorbankan perkuliahan dan mementingkan keluarga lebih diutamakan (Sari dan Nurwidawati, 2013).

Di sisi lain, riset juga menunjukkan hasil bahwa kondisi pernikahan pada mahasiswa dalam keadaan baik dan hanya diwarnai konflik-konflik kecil (Anisaningtyas \& Astuti, 2011) serta perubahan positif yang terjadi pada pasangan menikah dimana mereka secara pribadi merasa lebih dewasa dengan bertambahnya tanggung jawab (Juliawati, 2017) serta terpenuhinya kebutuhan akan cinta dan kasih sayang (Sari dan Nurwidawati, 2013).

Akhir tahun 2019 dengan ditemukannya virus Sars Covid-19 di Wuhan, Cina membuat perubahan yang sangat besar pada kehidupan masyarakat dunia. Penyebaran virus yang sangat cepat membuat kondisi dunia ditetapkan menjadi pandemi. Salah satu perubahan 
yang sangat terasa termasuk di Indonesia adalah diberlakukannya sekolah dan perkuliahan dari rumah atau perkuliahan yang dilakukan secara daring.

Kondisi perkuliahan secara daring membuat mahasiswa dapat lebih fleksibel ketika mengikuti perkuliahan karena bisa melakukan berbagai kegiatan secara bersamaan. Hasil riset menunjukkan bahwa beberapa mahasiswa lebih menyukai perkuliahan daring dikarenakan mahasiswa dapat lebih akrab dengan keluarga di rumah dan perkuliahan yang bisa dilakukan di manapun dan kapanpun (Rochimah, 2020). Di sisi lain, ada juga mahasiswa yang mengeluhkan kondisi perkuliahan daring dikarenakan banyaknya tugas yang diberikan oleh dosen dan sulit dalam memahami materi yang diberikan.

Data awal yang didapatkan dari mahasiswa Prodi Bimbingan Konseling Islam IAIN Parepare ditemukan bahwa 7 orang mahasiswa dari berbagai angkatan akan melangsungkan pernikahan bahkan di antaranya telah ada yang melangsungkan pernikahan. Hal tersebut dapat diduga disebabkan oleh kondisi pandemi yang mengharuskan mahasiswa lebih banyak di rumah atau di kampung dibandingkan berada di kampus serta bisa mengerjakan berbagai tugas secara bersamaan, termasuk melakukan perkuliahan sekaligus mengerjakan tugas rumah tangga. Dugaan tersebut sejalan dengan hasil wawancara dari salah satu mahasiswa yang akan menikah bahwa kondisi pandemi memberi peluang yang besar untuk dilamar, berdasarkan hasil wawancara berikut ini:

“...situasinya bisa dikatakan ada pengaruh karena pandemic covid19 yang mengharuskan kita di rumah saja membuat peluang dilamar jadi lebih besar. Sepertinya itu terjadi pada saya, apalagi saya yang sudah semester 7."

(NN/Wwnc/160521)

Adanya fenomena pernikahan pada saat menjalani perkuliahan, kondisi pandemi yang membuat waktu mahasiswa berpusat pada rumah, jumlah mahasiswa yang menikah di saat pandemi, serta hasilhasil riset yang menunjukkan pengaruh positif dan negatifnya melatarbelakangi peneliti untuk melakukan penelitian tentang intensi untuk menikah pada mahasiswa, khususnya di masa pandemi covid-19. Berdasarkan fakta-fakta yang sudah ada maka tujuan penelitian ini adalah menggali gambaran intensi menikah pada mahasiswa di masa pandemi covid-19 berdasarkan teori perilaku terencana (theory of planned behavior) dari Ajzen (Ajzen, 2005)

Fishbein dan Ajzen (1975) dalam Srimaryono dan Nurdibyanandaru (2013) mendefinisikan intensi sebagai kemungkinan individu dalam 
menampilkan suatu tingkah laku. Horn (Ajzen, 1988) mengemukakan bahwa intensi adalah istilah yang dikaitkan dengan tindakan dan menjadi unsur penting dalam sejumlah tindakan. Sedangkan Ajzen (1988) dalam Khumas, dkk (2015) mengemukakan bahwa intensi dapat digunakan untuk memprediksi sejauh mana kemungkinan suatu individu untuk menampilkan tingkah laku dan seberapa jauh usaha yang telah direncanakan atau dilakukan untuk menampilkan tingkah laku tersebut.

Intensi merujuk pada keadaan pikiran individu yang diarahkan untuk melakukan suatu tindakan, dimana tindakan tersebut dapat atau tidak dapat dilakukan, dan juga diarahkan pada tindakan sekarang atau tindakan yang akan datang. Intensi dapat berubah-ubah seiring berjalannya waktu. Dengan demikian definisi intensi pada penelitian ini merupakan derajat kemantapan individu untuk mewujudkan perilaku tertentu dalam hal ini menikah yang disertai dengan upaya sungguh-sungguh.

Teori intensi berdasarkan teori perilaku terencana (theory of planned behavior) memiliki tiga faktor yang merupakan determinan konseptual intensi berperilaku menurut teori perilaku terencana (Ajzen, 2005). Yang pertama adalah sikap terhadap perilaku (attitude towards the behavior) atau biasa didefinisikan sebagai tingkatan dimana seseorang mempunyai penilaian setuju/ bersikap positif atau tidak setuju/bersikap negatif terhadap perilaku tertentu beserta konsekuensinya. Kedua adalah norma partisipatif (subjective norm) yang merupakan tekanan sosial yang dirasakan berdasarkan pandangan orang lain untuk mewujudkan perilaku atau tidak. Dan yang ketiga adalah kontrol perilaku yang dirasakan (perceived behavioral control) yaitu perasaan mudah atau sulit mewujudkan perilaku atau keyakinan yang berkaitan dengan pencapaian spesifik dari perilaku. Dalam hal ini, tingkah laku yang dimaksud adalah menikah. Jadi intensi untuk menikah dapat dilihat dari sikap positif atau negatif terhadap pernikahan yang disertai pemahaman akan konsekuensinya, tekanan sosial yang dirasakan untuk menikah atau memutuskan pernikahan, dan perasaan mudah/sulit atau keyakinan mampu/tidak dalam menjalani pernikahan.

\section{METODE PENELITIAN}

Penelitian ini menerapkan pendekatan kualitatif dengan jenis penelitian yang digunakan adalah tipe penelitian kualitatif deskriptif. Unit analisis pada penelitian ini adalah intensi menikah dalam konteks pandemi covid-19 dengan 
mengambil data dari sumber data primer. Adapun informan pada penelitian ini adalah tiga orang mahasiswi IAIN Parepare dari fakultas yang berbeda yang akan menikah dan telah melalui proses lamaran, masing-masing berinisial UP, DMA, dan NA.

Teknik pengambilan data dilakukan dengan wawancara terstruktur kepada partisipan berdasarkan pedoman wawancara yang telah disusun yang diturunkan dari teori perencanaan perilaku dari Azjen (2005). Proses analisis data dilakukan dengan menggunakan model analisis interaktif oleh Miles dan Huberman yaitu pengumpulan data, reduksi data, presentasi/display data, lalu kesimpulan atau verifikasi.

\section{HASIL DAN PEMBAHASAN}

Intensi menikah pada mahasiswa di masa pandemi covid-19 dalam penelitian ini telah memenuhi kriteria penggunaan ATCT (action, target, context, time) dari Ajzen (2006) dalam Ramdhani (2011) untuk menjelaskan teori perencanaan perilaku. Aksinya berupa menerima lamaran, target berupa akad nikah, konteksnya pernikahan di masa pandemi, waktunya kurang lebih sebulan dari proses wawancara dilakukan.

Faktor determinan pertama dari teori perencanaan perilaku (Theory
Planned Behavior) adalah sikap/keyakinan terhadap perilaku (attitude towards the behavior). Ketiga partisipan menunjukkan sikap positif terhadap pernikahan dan memutuskan untuk menikah karena telah mengetahui manfaat dan mampu memprediksi konsekuensi negatif yang akan didapatkan dalam menjalani pernikahan dengan status ganda sebagai mahasiswa dan istri. Manfaat yang dirasakan berupa manfaat spiritualitas, dukungan ekonomi, dukungan emosi dan psikis, serta kesempatan untuk berbakti pada orangtua. Adapun konsekuensi yang mungkin akan didapatkan dari pernikahan adalah penambahan tugas dan pelaksanaan dari salah satu peran yang kurang maksimal, kurangnya waktu luang untuk istirahat dan berkumpul bersama teman, serta kondisi pernikahan jarak jauh. Sikap positif terhadap pernikahan juga ditunjukkan dengan komitmen partisipan untuk tetap melanjutkan pendidikannya meskipun pernikahan telah dilaksanakan. Menurut ketiga partisipan, pernikahan dan menempuh pendidikan dapat berjalan beriringan karena pendidikan cukup penting dalam menjalani rumah tangga, khususnya dalam mendidik anak.

Sikap positif terhadap pernikahan dari NA diperoleh atas keyakinannya akan mendapatkan manfaat spiritualitas dari menikah berupa terhindar dari dosa zina 
karena berpacaran serta dapat merasakan pacaran halal. Manfaat dari segi dukungan ekonomi berupa mengurangi beban orangtua dalam hal tanggung jawab ekonomi dan akan mendapatkan nafkah dari suami. Manfaat dari segi dukungan psikis dan emosi dengan peluang untuk menjadi lebih dewasa. Secara spesifik NA juga memiliki pandangan positif mengenai pentingya pendidikan dalam menjalani pernikahan. Adapun konsekuensi negatif yang telah dipikirkan adalah mengenai kemungkinan sulitnya pembagian waktu antara menjadi mahasiswa sekaligus berperan sebagai istri, terlebih ketika menjalani kehamilan sementara masih harus mengerjakan banyak tugas dari kampus serta konsultasi dengan dosen pembimbing.

Sikap positif terhadap pernikahan dari UP diperoleh atas keyakinannya akan mendapatkan manfaat berupa dukungan ekonomi dan emosional dari suami, dapat bepergian dengan aman untuk urusan kampus karena ditemani oleh suami, dukungan penyelesaian skripsi dari suami, serta pandangan bahwa pernikahan tidak menghalangi perempuan untuk berpendidikan tinggi. Adapun konsekuensi negatif yang dibayangkan adalah kesulitan pembagian waktu antara pengerjaan tugas kuliah dan tugas rumah serta kondisi stres karena perkuliahan yang dirasakan pada saat hamil nanti.

Sikap positif terhadap pernikahan dari DMA diperoleh atas keyakinannya bahwa menikah muda itu menyenangkan, niat menikah untuk beribadah, terhindar dari zina, dan meringankan beban orangtua. Adapun konsekuensi negatif yang dibayangkan adalah pembagian waktu yang tidak adil, terlebih jika telah memiliki keturunan serta kesadaran bahwa pernikahan akan membatasi waktu luangnya dan tidak sebebas seperti saat belum menikah. Selain itu, kondisi pernikahan yang akan dijalani adalah pernikahan jarak jauh karena suaminya berada di Kalimantan untuk bekerja dan DMA masih berada di Parepare untuk menyelesaikan studinya.

Ajzen (2005) mengemukakan bahwa sikap terhadap perilaku ditentukan oleh keyakinan mengenai konsekuensi dari suatu perilaku. Menurut Ramdhani (2011) keyakinan berkaitan dengan penilaian subjektif seseorang terhadap dunia sekitarnya serta pemahaman seseorang mengenai diri dan lingkungannya yang dilakukan dengan cara menghubungkan antara perilaku tertentu dengan berbagai manfaat dan kerugian yang mungkin diperoleh apabila individu melakukannya. Ketiga informan penelitian di atas telah menunjukkan penilaian subjektif terhadap kehidupan pernikahan yang akan 
dijalaninya serta menunjukkan pemahaman terhadap diri dan lingkungannya mengenai segala sesuatu tentang pernikahan yang dapat memberi manfaat sekaligus kerugian ketika memutuskan untuk menikah dengan status sebagai mahasiswa.

Faktor determinan kedua dari teori perencanaan perilaku adalah norma subjektif (subjective norm). Salah satu faktor yang cukup berpengaruh dalam pengambilan keputusan untuk menikah berdasarkan kategori norma subjektif adalah orangtua dan keluarga besar. Selain dari keluarga, norma subjektif lain yang memengaruhi adalah pandangan dari orang bahwa subjek merupakan anak yang berbakti karena mengikuti keinginan orangtua serta identifikasi atau meniru contoh dari kondisi mahasiwa lain yang telah menikah. Pada subjek NA dan DMA, keputusan menikah datang dari keputusan pribadi dan mendapat penguatan dari keluarga besar karena mereka telah menjalin hubungan atau berpacaran dengan calon suami masing-masing. Sedangkan pada subjek UP, keputusan untuk menikah sangat dipengaruhi oleh orangtua yang memintanya untuk menerima lamaran yang datang. Keyakinan ketiga partisipan untuk tetap melaksanakan pernikahan meskipun masih berstatus mahasiswa juga diperoleh dari melihat pengalaman mahasiswa lain yang telah menikah namun mereka tetap dapat melanjutkan perkuliahannya hingga selesai meskipun beberapa diantaranya menemui kendala ketika hamil sehingga harus menunda beberapa saat untuk menyelesaikan studinya.

Norma subjektif (subjective norm) menurut Ramdhani (2011) merupakan persepsi seseorang terhadap harapan dari orang-orang yang berpengaruh dari kehidupannya untuk melakukan perilaku atau tidak. Norma subjektif juga merupakan fungsi dari keyakinan individu yang didapatkan dari pandangan atau harapan dari orang lain untuk mewujudkan perilaku atau tidak. Dalam norma subjektif, pengaruh dapat diperoleh berdasarkan hubungan vertikal seperti orangtua kepada anak sehingga pengaruh tersebut lebih bersifat tuntutan. Selain itu, pengaruh juga dapat diperoleh dari hubungan horizontal seperti teman sehingga pengaruhnya lebih bersifat ingin meniru atau mengikuti perilaku orang lain di sekitarnya.

Pengaruh yang bersifat tuntutan dapat kita temui dengan jelas pada subjek UP dimana sebelumnya dia tidak mengenal calon suaminya dan tidak memiliki rencana untuk menikah, namun karena datangnya lamaran dan orangtua UP meminta untuk menerimanya sehingga keputusan untuk menikah didasarkan atas dorongan dari orangtua. Sedangkan pada subjek NA dan DMA, pengaruh bersifat tuntutan tidak 
terlalu signifikan memengaruhi pengambilan keputusan untuk menikah karena mereka bersama pasangannya masing-masing telah merencanakan pernikahannya meskipun masih berstatus mahasiswi. Pengaruh keluarga hanya bersifat dukungan dalam menerima rencana NA dan DMA dan proses lain menuju pernikahan.

Norma subjektif yang terlihat berdasarkan pertimbangan orangtua hanya terlihat pada harapan NA dan DMA untuk mengurangi beban orangtua dalam hal dukungan ekonomi karena akan mendapat nafkah dari suami yang telah bekerja sehingga dapat dipandang sebagai anak yang berbakti. Hal ini belum bisa dikategorikan sebagai bentuk tuntutan karena tidak didapatkan langsung dari orangtua, tetapi hanya pemikiran subjek saja. Adapun untuk pengaruh horizontal, ketiga subjek nampak ingin mengikuti atau meniru jejak teman-temannya yang telah menikah namun tetap mampu menyelesaikan studi meskipun beberapa diantaranya mengalami kendala.

Faktor determinan ketiga dari teori perencanaan perilaku adalah persepsi kontrol perilaku (perceived behavioral control). Ketiga subjek memiliki persepsi yang sama mengenai kesulitan yang akan dihadapi setelah menikah dengan statusnya sebagai mahasiswa. Namun demikian, ketiga subjek juga meyakini mampu mengontrol atau menghadapi kesulitankesulitan yang mungkin didapatkan setelah menikah dengan perilaku spesifik yang akan dijabarkan di paragraf berikutnya sehingga mereka memiliki intensi yang tinggi untuk menjalani pernikahan.

Pada subjek NA, persepsi kontrol perilakunya didukung dengan mengantisipasi berbagai kesulitan yang akan dihadapi setelah menikah dengan perilaku spesifik berupa mencoba membiasakan diri, tidak mengeluh, ikhlas, belajar manajemen waktu, serta upaya penyelesaian konflik yang hanya melibatkan suami-istri saja.

Pada subjek UP, persepsi kontrol perilaku didukung dengan perilaku spesifik berupa menjalani pernikahan dengan memperbanyak sabar dan syukur; berlatih coping stress, kontrol diri agar tidak mudah marah; tidak mencampuradukkan masalah keluarga dan kuliah; melakukan hal-hal yang menyenangkan pada waktu-waktu tertentu dengan membaca buku dan menulis di blog; curhat kepada teman yang dipercaya; menyelesaikan tugas kuliah semampu yang dilakukan; tidak segan meminta bantuan ketika mengalami kesulitan; menjalin komunikasi dengan pasangan sejak sebelum menikah terkait latar belakang, kebiasaan ibadah, hal yang disukai dan tidak disukai, dan rencana 
setelah menikah; mau mengakui kesalahan ketika berkonflik dan meminta maaf ataupun memaafkan, memilih diam ketika marah, mengkomunikasikan hal yang tidak disenangi, dan menerima perbedaan; serta tak lupa untuk berdoa dan bertawakkal pada Allah swt untuk menjaga pernikahannya.

Sedangkan pada subjek DMA persepsi kontrol perilakunya didukung dengan perilaku spesifik berupa meyakinkan diri sendiri untuk menikah karena telah memiliki kompetensi berupa kemandirian yang tinggi dan kemampuan mengolah keuangan dengan baik, menumbuhkan rasa saling percaya antar pasangan, belajar untuk tidak egois, memprioritaskan pekerjaan yang lebih penting, serta tetap menjaga komunikasi via whatsapp karena pernikahan yang akan dijalani adalah pernikahan jarak jauh.

Persepsi kontrol perilaku menurut Ajzen (2005) adalah persepsi individu mengenai mudah/sulit atau yakin/tidak untuk mewujudkan suatu perilaku. Ketiga partisipan penelitian memiliki persepsi yang sama yakni persepsi yang sulit untuk menjalani pernikahan dengan status ganda sebagai mahasiswi dan istri namun juga memiliki persepsi kontrol yang tinggi karena memiliki keyakinan akan sumber daya dan kesempatan sehingga mampu menghadapi kesulitan tersebut.
Menurut Ramdhani

(2011), individu yang memiliki persepsi kontrol tinggi akan terus terdorong dan berusaha untuk berhasil karena keyakinan akan sumber daya dan kesempatan yang dimiliki sehingga mampu menghadapi kesulitan yang dihadapi. Keyakinan seseorang bahwa ia memiliki kompetensi yang baik disertai dengan tersedianya fasilitas dapat meningkatkan kontrol perilaku. Dengan demikian dapat dilihat bahwa persepsi kontrol perilaku yang dimiliki oleh ketiga partisipan tergolong tinggi karena merasa memiliki kompetensi yang baik dalam menyelesaikan permasalahan serta memiliki fasilitas seperti media komunikasi untuk mencegah terjadinya persoalan dalam rumah tangga.

Berdasarkan pemaparan hasil penelitian di atas, didapatkan bahwa intensi menikah oleh mahasiwa di masa pandemi covid-19 didapatkan dari keyakinan yang tinggi akan manfaat yang diperoleh setelah menikah serta telah mampu mengantisipasi resiko yang akan dihadapi sehingga partisipan memiliki sikap positif terhadap pernikahan. Hal tersebut termasuk dalam ketegori faktor determinan sikap terhadap perilaku (attitude towards the behavior) yang memperkuat intensi menikah pada mahasiswa.

Faktor determinan berikutnya yang memperkuat intensi menikah adalah 
pengaruh dari orangtua dan keluarga serta upaya meniru pengalaman mahasiswa lain yang berhasil menyelesaikan studinya setelah menikah. Hal tersebut termasuk kategori norma subjektif (subjective norm).

Sedangkan faktor determinan ketiga yang memperkuat intensi menikah pada mahasiswa adalah perilaku-perilaku spesifik yang akan dilakukan dan diyakini mampu untuk mencegah terjadinya konflik atau dapat menjadi solusi untuk menyelesaikan konflik dalam rumah tangga. Hal ini disebut sebagai keyakinan kontrol atas pernikahan atau persepsi kontrol (perceived behavioral control).

Temuan lain dari penelitian ini adalah tidak adanya pengaruh konteks pandemi covid-19 dalam meyakinkan mahasiswa untuk menikah. Temuan selanjutnya adalah keyakinan terhadap agama serta kepatuhan terhadap ajaran agama menjadi sumber informasi yang memperkuat faktor determinan sehingga membentuk intensi dan perilaku.

\section{PENUTUP}

Intensi menikah pada mahasiswa di masa pandemi covid-19 dijelaskan dalam 3 faktor determinan, yaitu sikap terhadap perilaku (attitude towards the behavior), norma subjektif (subjective norm), dan persepsi kontrol perilaku (perceived behavioral control). Adapun Temuan pertama dalam penelitian ini bahwa tidak ditemukan pengaruh atas kondisi atau konteks pandemi covid-19 dalam membentuk intensi menikah pada mahasiswa. Intensi menikah muncul karena adanya sikap terhadap perilaku (attitude towards the behavior) berupa sikap positif terhadap pernikahan yang didapatkan dari keyakinan akan manfaat positif yang dibayangkan serta gambaran resiko yang akan dihadapi dalam menjalani pernikahan dengan status sebagai mahasiswa. Kemunculan intensi menikah berikutnya dibentuk oleh norma subjektif (subjective norm) berupa pengaruh orangtua serta keinginan untuk meniru pengalaman positif mahasiswa lain yang telah menikah namun mampu menyelesaikan studinya. Selanjutnya, intensi menikah pada mahasiswa dibentuk atas determinan faktor persepsi kontrol perilaku (perceived behavioral control) berupa keyakinan subjek akan kemampuannya mengontrol perilakunya dalam menjalani pernikahan sehingga dapat mencegah terjadinya konflik maupun mampu menemukan solusi dalam permasalahan rumah tangga yang akan dihadapi yang bersumber dari statusnya sebagai mahasiswa. Temuan lain dalam penelitian ini adalah keyakinan terhadap agama serta kepatuhan terhadap ajaran agama menjadi sumber informasi yang 
memperkuat faktor determinan sehingga membentuk intensi dan mewujud dalam perilaku dalam hal ini terjadinya pernikahan.

Adapun keterbatasan dalam penelitian ini adalah kurangnya penggalian informasi terhadap faktor-faktor yang menghambat munculnya intensi sehingga diharapkan penelitian berikutnya dapat melihat dua sisi yaitu faktor yang memperkuat munculnya intensi sekaligus faktor yang menghambat munculnya intensi sehingga dapat terlihat dinamika intensi yang terjadi pada mahasiswa dalam mengambil keputusan untuk menikah. Saran penelitian berikutnya juga dapat dilakukan penggalian informasi dari significant others seperti orangtua dan calon pasangan sehingga dapat dilakukan triangulasi data.

\section{DAFTAR PUSTAKA}

Anisaningtyas, G., \& Astuti, Y.D. (2011). Pernikahan di kalangan mahasiswa S-1. Proyeksi, Vol. 6 (2), 21-33.

Ajzen, I. (2005). Attitudes, Personality, and Behavior. New York: Open University Press.

Juliawati, D. (2017). Studi Kasus Terhadap Mahasiswa yang Menikah Saat Menempuh Masa Kuliah. Jurnal Tarbawi, Vol.13 (02).

Khumas, A., Prawitasari, J.E., Retnowati, S., \& Hidayat, R. (2015). Model Penjelasan Intensi Cerai Perempuan
Muslim di Sulawesi Selatan. Jurnal Psikologi, Vol. 42 (3). 189-206.

Mukarromah, R., \& Nuqul, F.L. (2012). Pengambilan Keputusan Mahasiswa Menikah Saat Kuliah Pada Mahasiswa UIN Maulana Malik Ibrahim Malang. In Proceding National Conference. Promoting Harmony in Urbancommunity: a Multy-Perspective Approach.

Putri, D., Suyono, H., \& Tentama, F. (2019, November). Memahami Kontrol Diri Terhadap Intensi Seks Pranikah Pada Remaja. In Prosiding Seminar Nasional Magister Psikologi Universitas Ahmad Dahlan (pp. 159-165).

Ramdhani, N. (2011). Penyusunan Alat Pengukur Berbasis Theory of Planned Behavior. Buletin Psikologi, Vol. 19 (2), 55-69.

Rochimah, F.A. (2020). Dampak Kuliah Daring terhadap Kseshatan Mental Mahasiswa Ditinjau dari Aspek Psikologi. (online). Psyarxiv.com

Sari, I.F., \& Nurwidawati, D. (2013). Studi Kasus Kehidupan Pernikahan Mahasiswa Yang Menikah Saat Menempuh Masa Kuliah. Character, Vol. 02 (02).

Srimaryono, F., \& Nurdibyanandaru, D. (2013). Intensi untuk Menikah pada Wanita Lajang. Jurnal Psikologi Keribadian dan Sosial, Vol 2 (2).

Zulfikar, H., \& Nurhayati, S.R. (2021). Strategi Coping pada Mahasiswa yang Sudah Menikah. Acta Psychologia, Vol. 3 (1), 38-45. 